\title{
ГЕОГРАФІЯ
}

UDC 551.509.5

Ellina Viktorovna Agayar,

$\mathrm{PhD}$ (Geography), Associate Professor,

Department of Meteorology and Climatology Odessa State Environmental University,

15 LvivskaStr, 65016, Odessa, Ukraine, e-mail: agayarellina@gmail.com, https://orcid.org/0000-0003-3914-6288;

Alina Borisovna Semerhei-Chumachenko,

$\mathrm{PhD}$ (Geography), Associate Professor,

Department of Meteorology and Climatology Odessa State Environmental University, e-mail: asemergey2016@gmail.com, https://orcid.org/0000-0001-8718-4073;

Svitlana Olekcandrivna Zubkovych,

$\mathrm{PhD}$ (Geography), Associate Professor,

Department of Geoinformation technologies and space monitoring of the Earth,

Kharkiv National Aerospace University, 17 Chkalov Str, 61070, Kharkiv, Ukraine, e-mail: szubkovych@gmail.com, https://orcid.org/0000-0002-6839-7572

\section{APPLYING PREDICTION MODELS FOR SHORT-TERM HAIL FORECASTING IN SOUTHERN UKRAINE}

Е. В.Агайар, А.Б Семергей-Чумаченко, С. О.Зубкович. ВИКОРИСТАННЯ ПРОГНОСТИЧНИХ МОДЕЛЕЙ ДЛЯ КОРОТКОСТРОКОВОГО ПРОГНОЗУ ГРАДУ НА ПІВДНІ УКРӒ̈НИ. Град є одним з основних джерел збитків житловим, комериійним і сільськогосподарським активам в Україні. Вивчення умов виникнення крупного граду, особливо не передбачених стандартними методами прогнозу випадків зі значним матеріальним збитком, має завжди високу актуальність. Підвищення справджуваності та завчасності штормових попереджень про випадіння граду є важливою проблемою оперативного метеорологічного забезпечення. Складність ї̈ вирішення обумовлена недостатньою точністю модельного прогнозування метеорологічних параметрів атмосфери, неточністю визначення часу $i$ місия виникнення конвективних явищ, рідкісної мережею спостережень і відсутністю, внаслідок иього, бази даних небезпечних явищ. У статті проаналізовані умови виникнення двох випадків градобою на території півдня України в 2017-2018 рр. У першому епізоді синоптики не прогнозували град, в іншому спостерігалося випадання надзвичайного граду $(D=65$ мм). Визначені синоптичні і термодинамічні умови виникнення граду. Оиінені можливості застосування різних індексів нестійкості атмосфери, а також використання прогностичних даних чисельного моделювання глибокої конвекиії (модель Global Forecast System - GFS) $з$ кроком сітки 0,25 × 0,25․ Виявлені найбільш інформативні параметри формування граду - Severe Weather ThrEAT індекс (скорочено SWEAT), Convective Available Potential Energy (скорочено CAPE), Li (Lifted Index), BRN (Bulk Richardson Number) ma BI (Bоyden I). Наведені рекомендачіï щуодо покращення якості короткочасного прогнозу граду з врахуванням даних чисельного моделювання.

Ключові слова: град, стихійні метеорологічні явища, конвективні процеси, моделювання глибокої конвекиії, індекси нестійкості атмосфери.

Е. В.Агайар, А.Б Семергей-Чумаченко, С. А. Зубкович ИСПОЛЬЗОВАНИЕ ПРОГНОСТИЧЕСКИХ МОДЕЛЕЙ ДЛЯ КРАТКОСРОЧНОГО ПРОГНОЗА ГРАДА НА ЮГЕ УКРАИНЫ. Град является одним из основных источников ущерба жильм. коммерческим и сельскохозяйственным активам на Украине. Изучение условий возникновения крупного града, особенно не предсказанных случаев и со значительным материальным ущербом, всегда имеет высокую актуальность. Повыпение оправдываемости и заблаговременности штормовых предупреждений о возникновение града является одной из основных и главных задач, которые возникают при оперативном метеорологическом обеспечении. Сложность ее решения обусловлена недостаточной точностью модельного прогнозирования метеорологических параметров атмосферы, неточностью определения времени и места возникновения конвективных явлений, редкой сетью наблюдений и отсутствием, в результате этого, базы данных опасных явлений. В статье проанализированы условия возникновения двух случаев градобития, зафиксированных на территории юга Украины в 2017-2018 гг. В первом эпизоде синоптики не прогнозировали град, в другом наблюдалось выпадение чрезвычайного града $(D=65$ мм). Рассмотрены синоптические и термодинамические условия возникновения града. Оиениваются возможности применения различных индексов, рассчитывающих параметры неустойчивости атмосферы, а также использования прогностических данных численного моделирования глубокой конвекиии

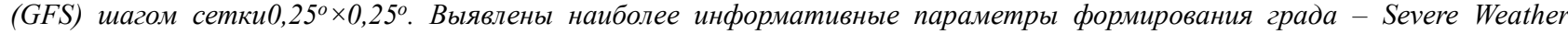
ThrEAT индекс (сокращенно SWEAT), Convective Available Potential Energy (CAPE), Li (Lifted Index). BRN (Bulk Richardson Number) и BI (Boyden Index). Приведены рекомендации по улучшению качества кратковременного прогноза града с учетом данных численного моделирования.

Ключевые слова: град, стихийные метеорологические явления, конвективные прочессы, моделирование глубокой конвекиии, индексы неустойчивости атмосферы.

Formulation of the problem. The geographconditions and the features of the synoptic processes ical position of Ukraine, the diversity of climatic on its territory contribute to the complex spatial and (C) Agayar E. V., Semerhei-Chumachenko A. B., Zubkovych S. O., 2020 https://doi.org/10.26565/2410-7360-2020-53-05 
temporal distribution of the occurrence of natural meteorological phenomena (NMP). In recent years, the frequency of extreme weather phenomena has increased due to significant climate fluctuations [8]. Often natural disasters cause significant damage to the economy and the population, having a devastating nature, especially when a complex of dangerous weather conditions is created. These weather conditions mutually reinforce their negative impact: storm rains accompanied by storm winds, thunderstorms with hail, etc.

Increasing the validity and timeliness of storm warnings about hail occurrence is one of the main urgent tasks of operational meteorological support. The complexity of its solution is due to insufficient accuracy of model forecasts of meteorological parameters of the atmosphere, inaccuracy in determining the time and place of convective phenomena occurrence, a rare network of observations.

Analysis of previous research and publications. The current state of the problem of hail cloudiness forecasting is characterized by the accumulation of theoretical and experimental material on the macro- and microstructural characteristics of clouds - V. Findaisen [10] G.K. Sulakwelidze [7], S.M. Schmeter [11], M.V. Bukov [2] etc. [1,5,9]. Foreign experience also indicates the relevance of the study of climatology, the dynamics of formation and prediction of strong hail (Bedka 2011; Dworaketal. 2012) [13-23, 25-27]. Methods of convective phenomena forecasting using empirical parameters of atmospheric instability are now popular $[3,4,12]$. In operational prognostic practice in Ukraine, the possibility of using these parameters is rather limited due to insufficient software, so research of this issue is relevant.

The purpose of the research is to study the synoptic and thermodynamic conditions of large hail occurrence in the territory of southern Ukraine, as well as the possibility of using forecasting models for short-term forecast of hail.

The source material was meteorological observation data (ARMSin), Wetterzentrale [29], logs of storm warnings of HMC BAS, interactive databases of the European Severe Storms Laboratory ESSL [30] site at the specified dates. To analyze the humid and dynamic parameters of the troposphere in the implementation of dangerous meteorological phenomena, we used an atmospheric radiosonde data set at 00.00 UTC and numerical simulations (GFS) with a spatial separation of $0.25 \mathrm{o} \times 0.25 \mathrm{oM}$ at the stations of Odessa-HMO (Odessa-Observatories) and Yuzhnoukrainsk of Nicolayiv region (at 12.00 and 15.00 UTC).

Methods and presentation of the study material. Heavy hail in the summer is possible for the whole territory of Ukraine, and quite often this phe- nomenon is observed in the southern regions of the country [8]. For the period of 2009-2018, hazardous weather database of The Black and Azov Seas Hydrometeorological Center provides information about 20 hailstorms. And it is reported about 56 hailstorms according to the European Severe Weather Database (ESWD)[30].

Many of these cases were not predicted, including no storm warnings, so the study of hail occurrence conditions with significant material damage, especially not predicted by the forecast, is most relevant.

Two cases of hail fall in the Northwest Black Sea region during the warm period of 2017 and 2018 were selected for the research, which are related to the synoptic processes that led to the development of powerful convection. The first one was observed in the area of Odessa-AMSC and OdessaHMO stations on May 20, 2017 between 14.23 and 15.00 of local time ( $\mathrm{D}=8 \mathrm{~mm}$ ), but was not forecasted. The second case is an extraordinary hail (D $=65 \mathrm{~mm}$ ), which was registered on 28.06 .2018 at 15.05 UTC in the territory of the Nikolaev region near Yuzhnoukrainsk city. In both cases, the possibility of using different indices, which calculate the parameters of the instability of the atmosphere, as well as the possibility of modeling deep convection, are considered.

The first case. On May 20, 2017, the territory of the Odessa region was influenced by a basin of low pressure, oriented from the north, which the system of occlusion front located in the east of the region was connected with. The intensity of the high-altitude frontal zone (AFZ) over the region was 20 dam $\backslash 1000 \mathrm{~km}$. The thermobaric field of the upper and middle troposphere was represented by a kernel of cold over the eastern part of Ukraine, which occupied the territory of the Odessa region and may contribute to the formation of deep convection zones [6]. The value of relative geopotential in the center of the reduced pressure over the east of Ukraine reached 552 dam. The advection of cold spread from the northeast to the southwest to areas of the Balkan Peninsula. Intense vertical upward flows of $10-20 \mathrm{hPa} / \mathrm{h}$ were observed on the surface of the AT-500. On the AT-850 map, the region of reduced pressure occupied the entire territory of eastern Ukraine and the Azov-Black Sea basin, and the cold center with a temperature of $2^{0} \mathrm{C}$ was located over eastern Ukraine.

Thus, in the lower layers above the Odessa region advection of warm air was observed, which increased the possibility of hail formation. According to the precipitation distribution map at 12.00 UTC, the precipitation zone with the intensity of $15-$ $20 \mathrm{~mm} / 3 \mathrm{~h}$ was located above the territory of Odessa region. (Fig. 1). 


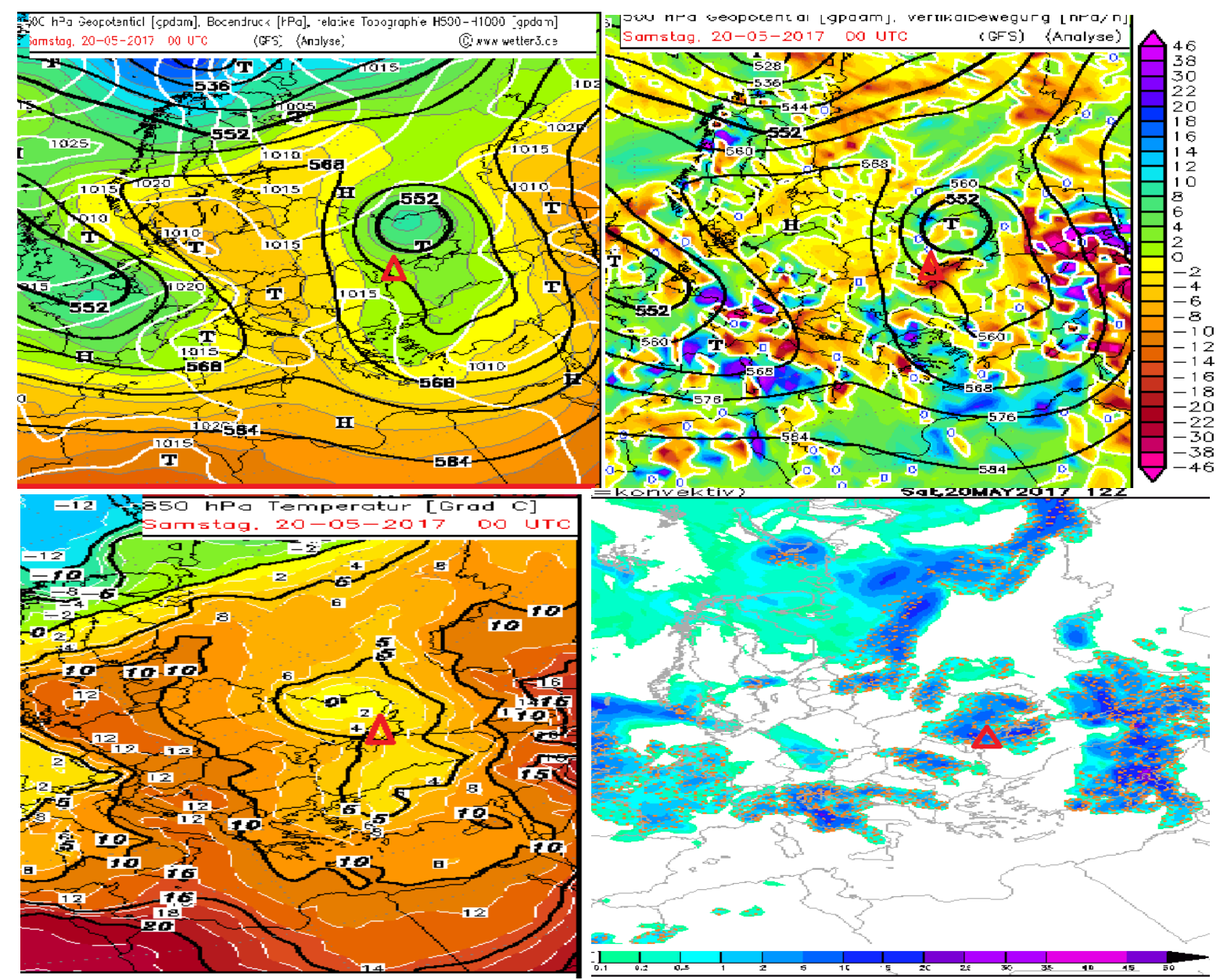

Fig. 1. Maps VT-500/1000, AT-500 (vertical streams), AT-850 and precipitation fields, 20.05.2017 00 UTC [29]

The low-gradient high-pressure baric field at the earth's surface caused a relatively weak wind (2$3 \mathrm{~m} / \mathrm{s}$ ), and a surface inversion was also observed. The transition from ground-level anticyclone circulation to cyclonic circulation in the middle and upper troposphere was determined by a sharp increase in wind from an altitude of 700-800 m (Fig. 2a).

According to the temperature-wind sounding at the Odessa-HMO station at $00 \mathrm{UTC}$, the level of convection was $470 \mathrm{hPa}$. The vertical temperature gradient in the 984 to $720 \mathrm{hPa}$ layerwas dry adiabatic and in the 700 to $560 \mathrm{hPa}$ layer exceeded the moisture adiabatic one. The magnitude of the instability energy increased above the $700 \mathrm{hPa}$ level, where the average deviation of the state curve from the stratification curve was $20 \mathrm{C}$ (Fig. 2b).

The condensation level was at an altitude of $810 \mathrm{hPa}$, which is high enough for convective precipitation. The air mass at the surface up to the level of $600 \mathrm{hPa}$ was dry (42-35\%), but at the level of 580 $\mathrm{hPa}$ the relative humidity reached $90 \%$, a sharp decrease of humidity up to $18-23 \%$ was observed above. Such a distribution of humidity increased the potential instability of the air mass. The wind velocity in the surface layer was $2-3 \mathrm{~m} / \mathrm{s}$, increasing in the middle troposphere to $15 \mathrm{~m} / \mathrm{s}$. A sharp increase of wind speed was observed from the level of 300 to $200 \mathrm{hPa}$, where jet current was detected at a speed of above $30 \mathrm{~m} / \mathrm{s}$. Thus, the vertical distribution of thermodynamic parameters of air mass according to the data of night sounding at Odessa station was not typical for the formation of hail clouds, so in order to predict the development of powerful convection, which can cause hail, information that is close to the time of the event is needed.

At present 26 indices of instability are widely known in the world, which are used to predict convective instability phenomena $[12,28]$. For the hail forecast observed at the meteorological stations Odessa-Airport and Odessa-HMO on 05/20/2017, in the framework of this study 9 parameters of convective instability of the atmosphere were used. The calculation of the instability indices was performed according to the objective analysis of GFS (Global Forecast System), with a grid step of $0.25 \mathrm{o} \times 0.25 \mathrm{o}$ $M$. The values of the calculated indices are presented in Table. 1. In addition, according to data of the objective analysis using an specialized RAOB software, an aerological chart was constructed at 09.00 UTC 20.05.2017 (Fig. 3). 


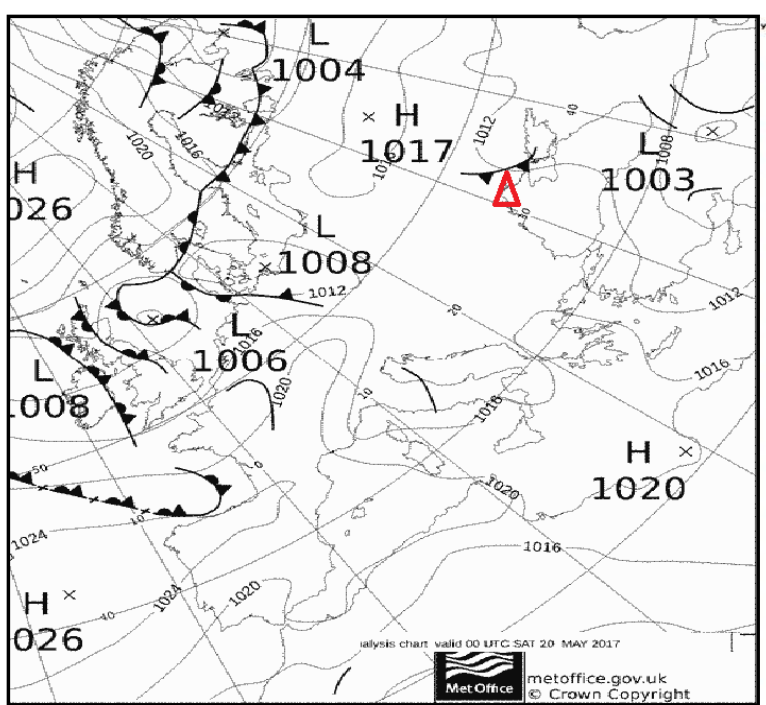

a)

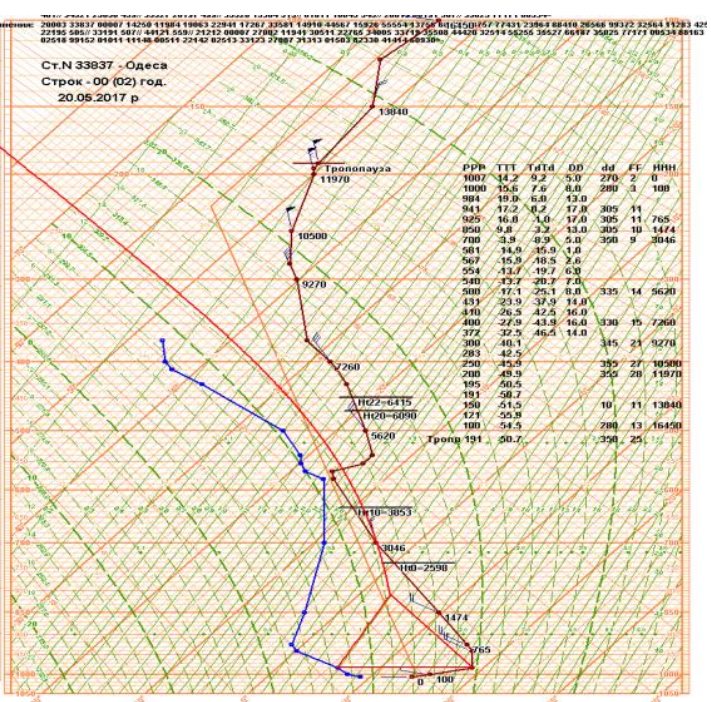

b)

Fig. 2. Ground analysis 20.05.2017. 00 UTC

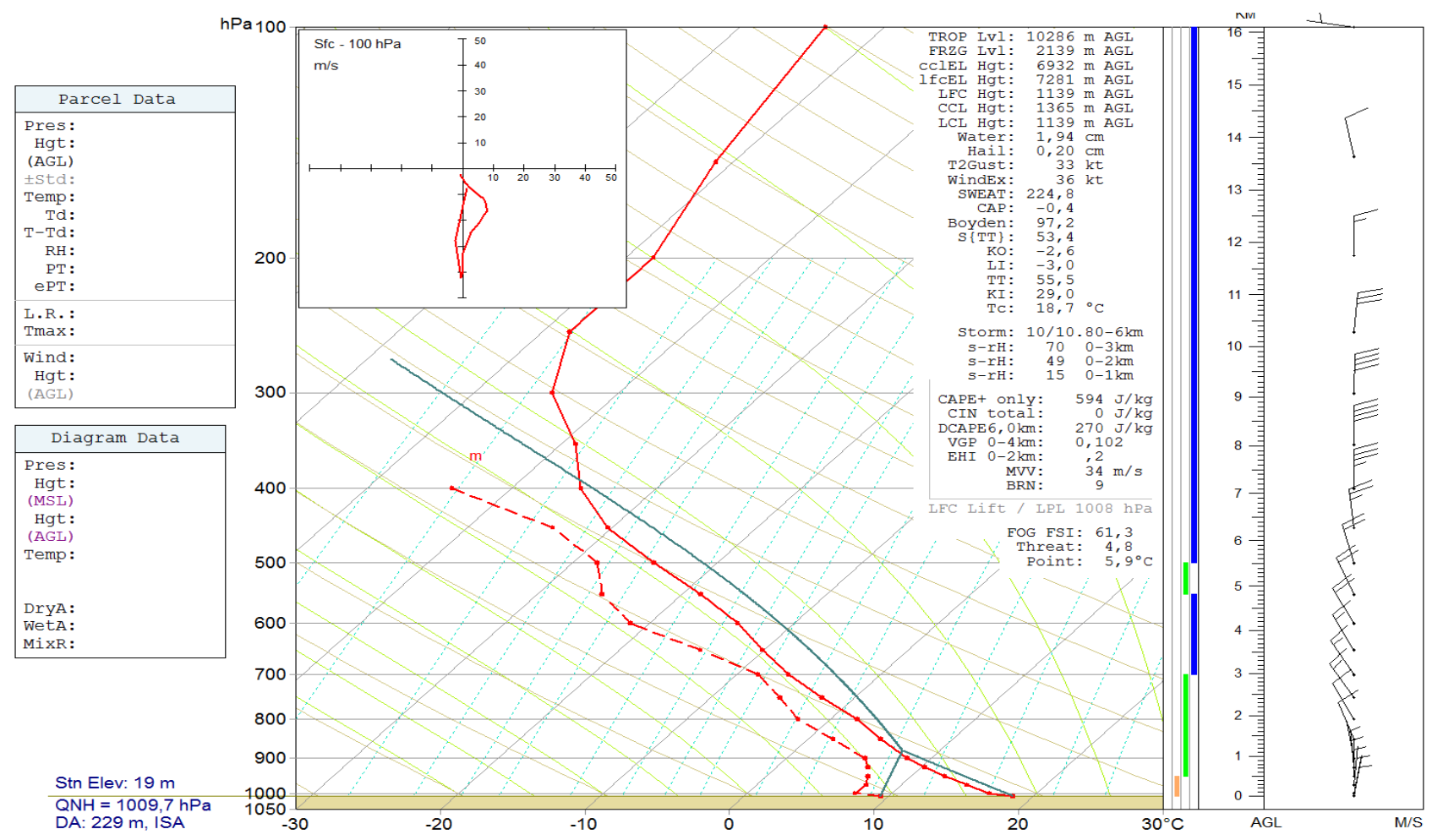

Fig. 3. Aerological chart for 12 UTS 20.05.17, Odessa-HMO station

Moderate thermal instability was observed in the hail development zone at 09.00 UTC, as confirmed by SBCAPE (594 J / kg), that is characteristic for thunderstorms occurrence, moderate Lifted Index $\left(-3^{\circ} \mathrm{C}\right)$, high TT index (55.5) and Boyden index. $(97,2)$. In addition, in the middle and upper troposphere wind speed increase up to $17-20 \mathrm{~m} / \mathrm{s}$ was observed. Also, according to the CFS analysis, a hail size of $20 \mathrm{~mm}$ was determined. The SWEAT index, which takes into account both wind velocity and displacement as well as thermal instability in the troposphere, was also close to critical (250).

Analysis of the vertical distribution of tropospheric wind characteristics was performed accord- ing to the data of the troposphere radiosound, and the variability of the actual tropospheric wind was estimated by the hodograph (Fig. 3). The wind hodograph can be set parametrically by two functions: changing the wind speed module and the wind azimuth with altitude, with the beginning of each next vector being delayed from the end of the previous one. The hodograph gives a clear idea of the most likely directions for the transfer of air flows, changes in the direction and speed of wind. The May 20, 2017 data show a steady northern wind direction and increased wind speed with the altitude.

Thus, the high probability of hail emergence was indicated by the presence of moderate thermal 
Table 1

Values of atmospheric instability parameters according to indices calculated from objective GFS analysis

\begin{tabular}{|l|l|}
\hline \multicolumn{1}{|c|}{ Indices } & \multicolumn{1}{c|}{ Index values } \\
\hline SBCAPE $(\mathrm{J} / \mathrm{kg})$ & 594 \\
\hline SBCIN $(\mathrm{J} / \mathrm{kg})$ & 0 \\
\hline BoydenI & $\mathbf{9 7 , 2}$ \\
\hline VGP & 0,102 \\
\hline $\mathrm{Li}\left({ }^{\circ} \mathrm{C}\right)$ & $\mathbf{- 3}$ \\
\hline KI & 29 \\
\hline SWET & $\mathbf{2 2 4 , 8}$ \\
\hline TT & $\mathbf{5 5 , 5}$ \\
\hline SRH $_{0-3} \mathrm{~km}\left(\mathrm{~m}^{2} / \mathrm{s}^{2}\right)$ & 70 \\
\hline
\end{tabular}

instability with the level of convection development $7281 \mathrm{~m}$, high values of the SWEAT index, TT index and Boyden index. It should also be noted that local conditions, such as the presence of a land-sea delimitation, played a significant role in the formation of hail in the coastal zone.

In this case, the difficulty of hail predicting near Odessa on May 20, 2017 first of all can be explained by the absence of a radiosounding in the afternoon, because night sounding cannot provide information for the prediction of convective phenomena that develop in the afternoon. Also, a rare network of aerological stations does not allow obtaining actual information on the thermodynamic characteristics of the troposphere in the region. But a significant impact on the success of forecasting hazardous meteorological phenomena that are locally and "explosive" in nature can have the use of high spatial resolution forecasting models and objective analysis data from GFS or other resources.

The second case was observed on June 28, 2018, when the territory of the Mykolaiv region was influenced by the warm sector of cyclone with the center over the Balkans and a minimum pressure of $1005 \mathrm{hPa}$ (Fig. 4a). An occluded polar frontal sys-

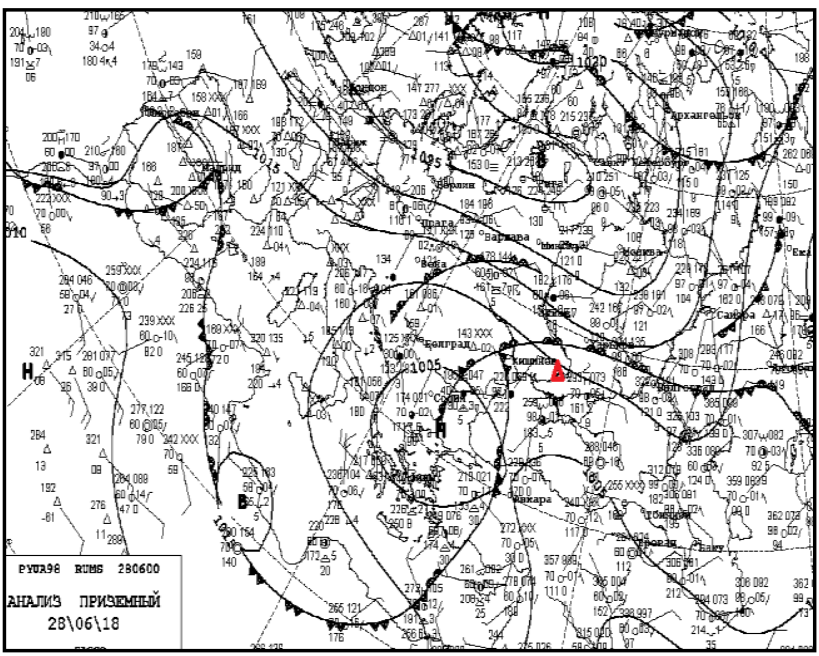

a) tem is associated with this baric formation. In the daytime the air near the surface warmed to $28-34^{\circ}$ $\mathrm{C}$, except in the northwestern regions, where due to the cloudness of the cold front, warming was negligible (up to $19-21^{\circ} \mathrm{C}$ ). The advection of heat in the lower troposphere and the focus of cold at an altitude of $5 \mathrm{~km}$ and above determined the thermobaric structure of the altitude field of pressure over the territory of southern Ukraine. Such distribution of heat and cold zones by altitudes is one of the characteristic prognostic features of the possibility of forming a heavy hail cloudness. According to the circular map at $15.00 \mathrm{UTC}$, the polar front with waves and a linear system of cumulonimbus clouds (Fig. 4b) was passing in the area of Yuzhnoukrainsk and the atmospheric pressure decreased to 999.7 $\mathrm{hPa}$. Meteosat satellite data confirm the presence of a series of mesoscale convective complexes (MCC) over southern Ukraine (Fig. 5), where heavy rains, thunderstorms and hail were observed.

To verify the methodology of hail forecast according to the data of objective analysis of GFS and specialized RAOB software, an aerological chart was constructed for June 28, 2018 for the meteorological station Yuzhnoukrainsk, Mykolaiv region

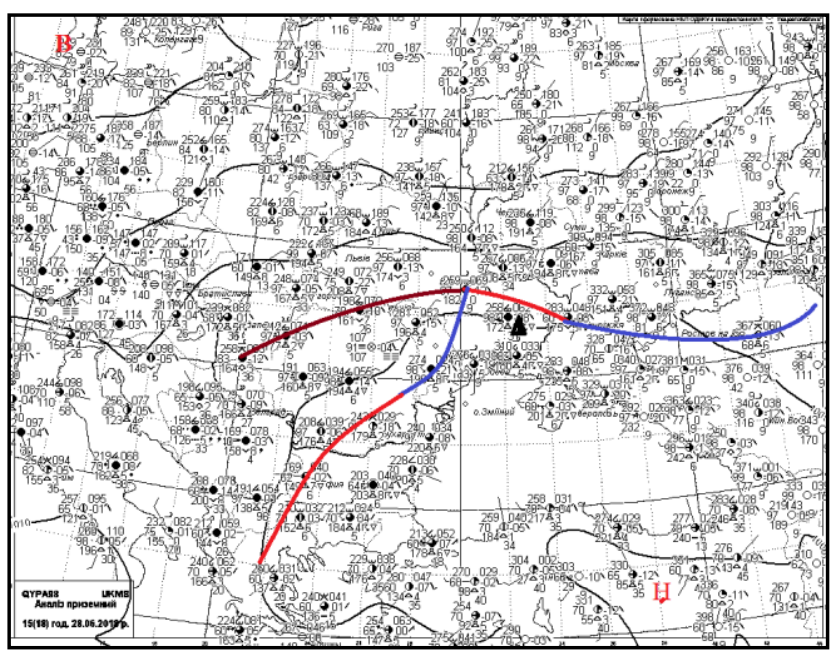

b)

Fig. 4. Surface map 28.06.2018. 06.00 UTC 


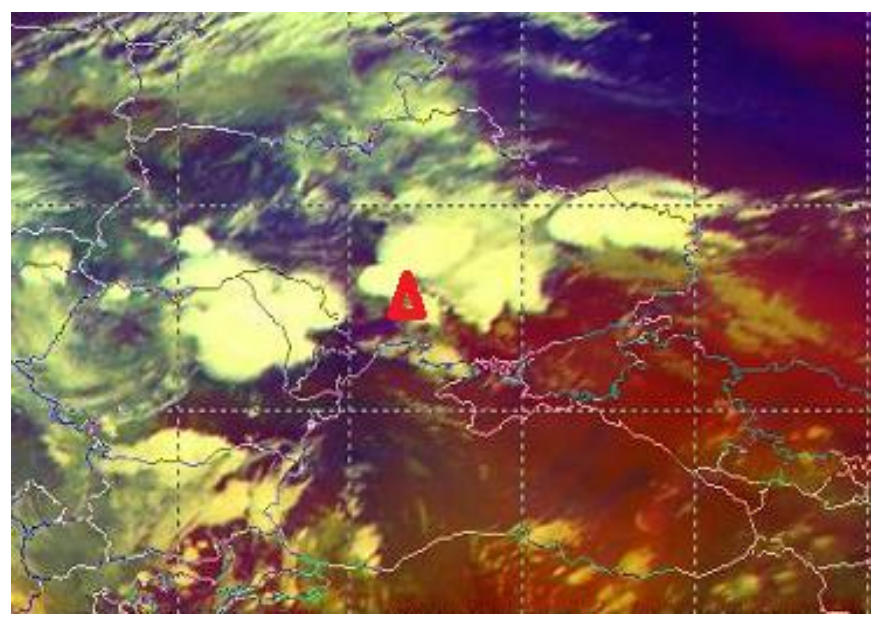

Fig. 5. Satellite data 28.06.2018. 15.00 UTC

(Fig. 6), at which an extraordinary hail was registered at 15.05 UTC. The size of the hailstones was $65 \mathrm{~mm}$, which is 1.5 times higher than the criteria of the MFI III (D>40 mm). According to model data at 15 UTC, a hail of 1.33 inches $(34 \mathrm{~mm})$ was forecasted.

The parameters of convective instability of the atmosphere in this case were classified depending on which layers of the atmosphere were evaluated by the instability degree as the main predictor of hail hazard. Most indices estimate the instability degree in the cloud layer (Table 2) or the cloud and undercloud layers (Table 3). This is explained by the fact that the ascending vertical movements start in the warm humid air of the undercloud layer, and in the cloud layer they intensify, where hydrometeors (water droplets, ice particles, snow groats) accumulate $[2,10,11]$. The indices given in the table describe the instability degree of the atmosphere quite well and allow to determine the development of high-probability hail cloudiness. Almost all parameters reach or exceed limits. The SBCAPE parameter, which is a measure of the instability of the atmosphere, shows "strong instability" (2500-4000 Jkg-1), the Boiden index - 97.2 (the higher the index, the higher the probability of thunderstorms), the index $\mathrm{K}$ exceeds the critical value twice (20 and above), the Index Li also has a critical limit (-80C).

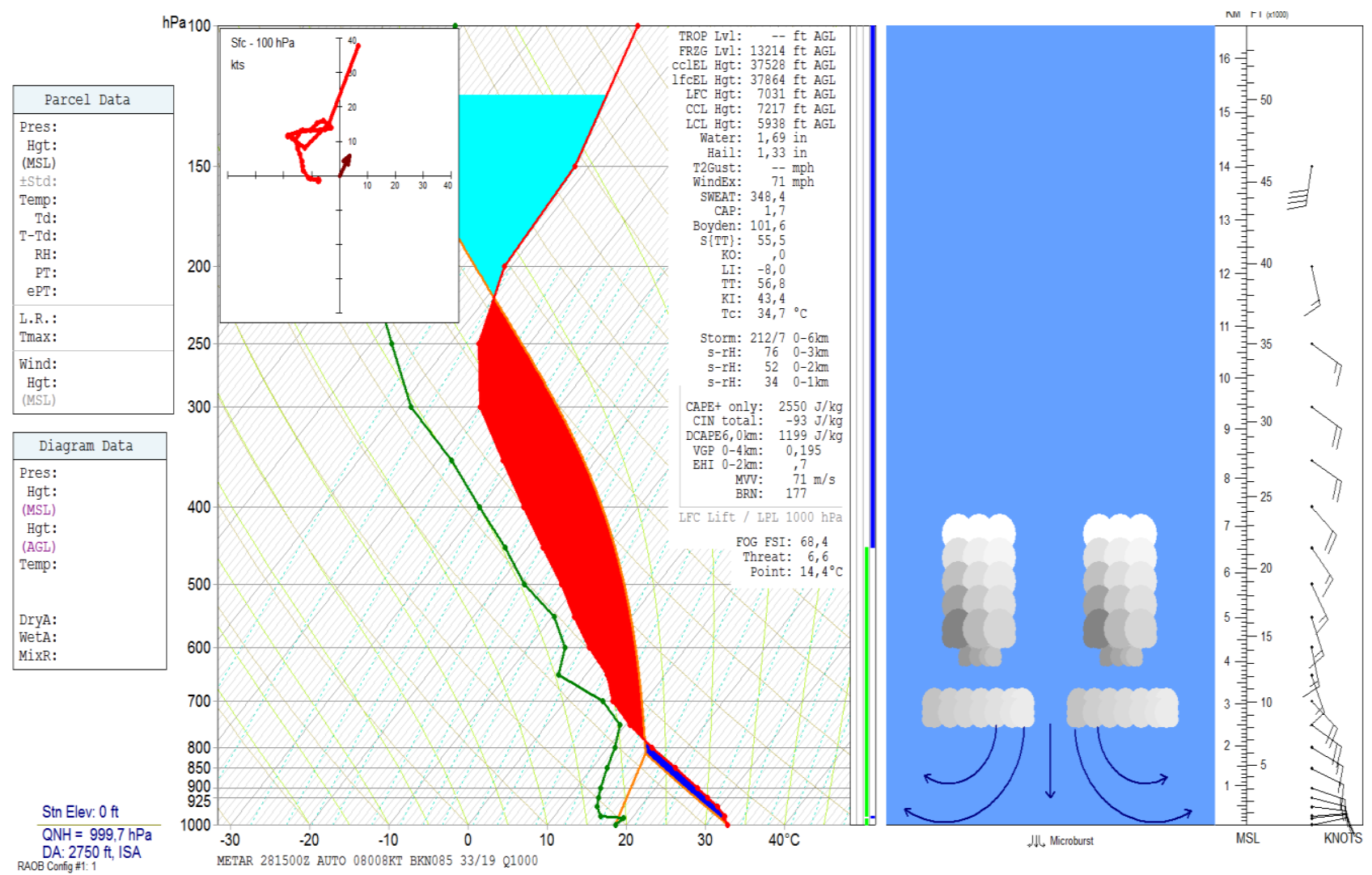

Fig. 6. Aerological diagram of the Yuzhnoukrainsk station.15.00 UTC. 28.06.18 
Atmospheric indices, which estimate the instability degree of a cloud layer

Table 2 according to the objective analysis of GFS 06.28.2018

\begin{tabular}{|c|c|}
\hline Indices & Index values \\
\hline SBCAPE $(\mathrm{J} / \mathrm{kg})$ & 2550 \\
\hline DCAPE $(\mathrm{J} / \mathrm{kg})$ & 1199 \\
\hline BoydenI & 97,2 \\
\hline VGP & 0,195 \\
\hline KI & 43,4 \\
\hline SWEAT & 348,4 \\
\hline TT & 56,8 \\
\hline
\end{tabular}

Atmospheric instability indices, which evaluate the instability degree of cloud and

Table 3 undercloud layers according to the data of objective analysis of GFS 06.28.2018

\begin{tabular}{|c|c|}
\hline Indices & Index values \\
\hline SBCIN $(\mathrm{J} / \mathrm{kg})$ & -93 \\
\hline BoydenI & 101,6 \\
\hline VGP & 0,195 \\
\hline $\mathrm{Li}\left({ }^{\circ} \mathrm{C}\right)$ & -8 \\
\hline
\end{tabular}

A characteristic feature of this case is the alternation of wet and dry layers in the troposphere. A moist layer of 1.5-2.0 km lies above the boundary layer of the atmosphere, above which threre is a relatively dry layer. A significant shortage of humidity in the surface layer $\left(16^{\circ} \mathrm{C}\right)$ is also one of the predictors of the spontaneous hailstorm occurrence[11].
The trajectory of hail cloud movement in the area of Yuzhnoukrainsk is directed by the quasilatitude (with azimuth of motion of about 90-130 ${ }^{\circ}$ ) in the layer of $0-3 \mathrm{~km}$. (Fig. 7), which is more accurately predicted by the Bunkers method [15, 20, 24]. But above the 3-kilometer layer there was a shear of the wind and the vorticity of the flow was clearly
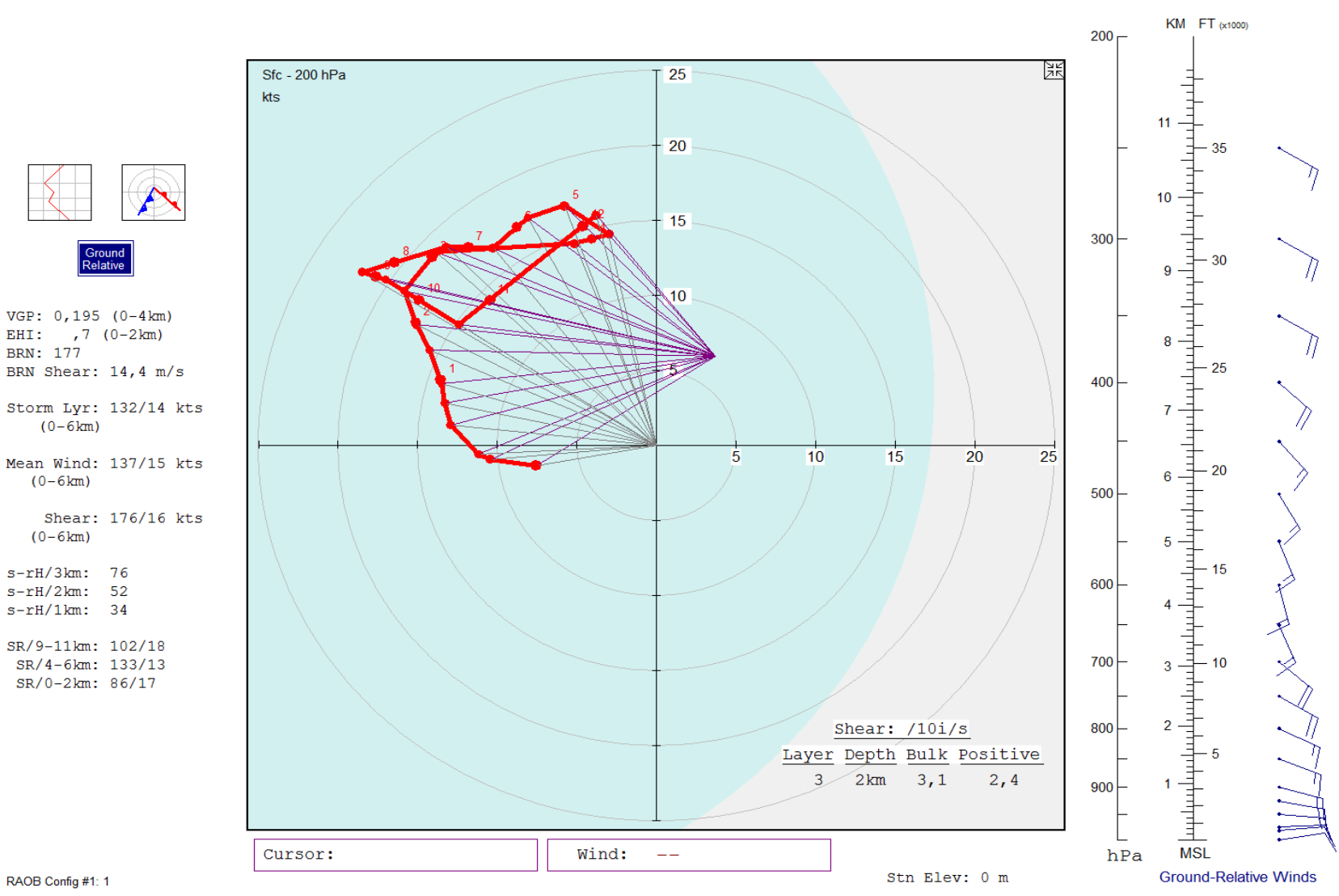

Fig. 7. Calculation of convective storm motion vector. Yuzhnoukrainsk station 15.00 UTS. 06.28.18 
observed, which can be estimated by the shape and length of the hodograph as well as by the values of the Storm Relative Helicity (s-rH) index In this case, the value of s-rH was $76 \mathrm{~m}^{2} / \mathrm{s}^{2}$ and there was a right turn of the wind with height (the so-called "right storm") and an increase in the swirling upward flow in the middle troposphere. The vertical shear of the BRNshear horizontal wind was $14.4 \mathrm{~m} /$ $\mathrm{s}$. The BRN index estimates the instability energy of a convective cloud and the vertical displacement of cumulus-rain cloud $(\mathrm{Cb})$ layers relative to each other as it evolves, and includes floating energy (CAPE) and vertical horizontal wind shear, which in turn are the critical factors that determine the development, evolution and formation of a storm. In this case, the index value was quite high and reached 177. This indicator shows the presence of relatively weak vertical wind shear and high CAPE, which implies the highest probability of a multi-chamber thunderstorm.

\section{Conclusions.}

- High values of the SWEAT, CAPE, Li (buoyancy parameter), BRN and Boyden I indices can be considered as the most informative predictors for hail forecasting according to the data of global hydrodynamic atmospheric models.

- The use of products of numerical simulation and taking into account the trend of changes in thermodynamic parameters with simultaneous analysis of features of synoptic position and regional conditions can improve the quality of the convective phenomena forecast (including hail).

\section{Bibliography}

1. Аиабоков Б.А. Физика градовых облаков и активных воздействий на них: состояние и направления развития / Б.А. Ашабоков, Л.М. Федченко, В.О. Тапасханов, А.В. Шаповалов, и др // Нальчик: ООО «Печатньй двор». $-2013 .-216 c$.

2. Буйков М.В. О росте града в суперячейковых градовых облаках. Метеорология и гидрология / М.В Буйков, А.Г. Кузьменко. - 1978. - №11. - С. 6-15.

3. Быков А.В. Прогноз опасных конвективных явлений в Пермском крае с использованием глобальных прогностических моделей / А.В. Быков, А.Л. Ветров, Н.А. Калинин // Труды Гидрометцентра России, 2017. - Вып. 363. - C. 101-119.

4. Грушевський О.М. Про можливості діагнозу і прогнозу глибокої конвекиї в оперативній діяльності / О.М. Грушевський, Н.М. Міщенко, В.Ф. Мансарлійський, В.М. Буриев // Украйнський гідрометеорологічний журнал, 2018. - № 22. - C. 5-15.

5. Данов Е.И. К анализу суперячейкового градового иторма в Причерноморье/ Е.И. Данов, Т.Е. Данова // Метеорология, климатология и гидрология: Межведомственный научный сборник Украины, 2001. - Bып. 44. - C. 61-66.

6. Руководство к прогнозу опасных осадков, града и шквалов по данным метеорологических радиолокаторов и искусственных спутников Земли. СПб.: Гидрометеоиздат, 1996.

7. Сулаквелидзе Г.К. Ливневые осадки и град / Сулаквелидзе Г.К. - Л.: Гидрометеоиздат, 1968. - 412 c.

8. Стихійні метеорологічні явища на території Украӥни за останнє двадчятиріччя (1986-2005 рр.) // За редакиією В.М. Ліпінського, В.І. Осадчого, В.М. Бабіченко. - Украӥнський науково-дослідний гідрометеорологічний інститут. Державна гідрометеорологічна служба. . - Київ: Ніка-Центр, 2006. - 312 с.

9. Толмачева Н.И. Исследование параметров облачности и явлений по данным спутникового и радиолокационного зондирования / Н.И.Толмачева, Л.Н. Ермакова // Географический вестник, 2011. - № 3.

10. Финдайзен В. Экспериментальные исследования образования ледяных частии. Физика образования осадков / В. Финдайзен, Г. Шульи. - М., 1951. - 312 с.

11. Шметер С.М. Термодинамика и физика конвективных облаков. - Л.: Гидрометеоиздат. 1987, - 287 с.

12. Andersson T. Thermodynamic indices for forecasting thunderstorms in southern Sweden / T. Andersson, M. Andersson, C. Jacobsson, S. Nilsson // Meteorol. Mag. - 1969. - Vol. 116.- P. 141-146.

13. Bedka K.M. Overshooting cloud top detections using MSG SEVIRI infrared brightness temperatures and their relationship to severe weather over Europe / K.M. Bedka // Atmos Res. - 2011. - Vol. 99(2). - P. $175-189$. https://doi.org/10.1016/j.atmosres.2010.10.001

14. Browning K.A. Airflow and hail growth in super-cell storms and some implications for hail suppression [Text] / K.A. Browning, G.B. Foote // Nation. Hail Research Exper. - 1975. - №75/1.

15. Bunkers, M.J. Predicting supercell motion using a new hodograph technique. Weather and Forecasting [Text] / M.J. Bunkers et al. - 2000. - Vol.15. - P. 61-79.

16. Craven J.P. Baseline climatology of sounding derived parameters associated with deep, moist convection [Text] $/$ J.P. Craven, and H.E. Brooks // Natl. Wea. Dig. - 2004. - Vol.28. P. 12-24.

17. Doswel C.A. On the use of indices and parameters in forecasting severe storms [Text] / C.A.Doswel, D.M. Schultz // Electron. J. Sev. Storms Meteorol. - 2006. -Vol. 1. - P. 1-14.

18. Dworak R. Comparison between GOES-12 overshooting-top detections, WSR-88D radar reflectivity, and severe storm reports. [Text] / R. Dworak, K.M. Bedka, J. Brunner, W. Feltz // Weather Forecast. -2012. - 27(3). - P. 684699. https://doi.org/10.1175/WAF-D-11-00070.1

19. Fawbush E.F. A method for forecasting hailstone size at the earth's surface. [Text] / E.F. Fawbush and R.C. Miller // Bull. Amer. Meteor. Soc. - 1953. - Vol. 34. - P. 235-244. 
20. Kahraman A. Severe Hail Climatology of Turkey [Text] / A. Kahraman, S. Tilev-Tanriover, D.M. Schultz // Monthly Weather Review. - January 2016. -. 144(1):337-346. https://doi.org/10.1175/MWR-D-15-0337.1

21. Mossop S.C. The origin and concentration of ice crystals in clouds [Text] / S.C. Mossop // Bull. Amer. Soc. - 1982. Vol. 66. - P. 264-273.

22. Punge H.J. A new physically based stochastic event catalog for hail in Europe [Text]/ H.J. Punge, K.M. Bedka, M. Kunz, A. Werner // Springer. - 2014. https://doi.org/10.1007/s11069-014-1161-0

23.Tuovinen J. Climatology of severe hail in Finland: 1930-2006 [Text] / J. Tuovinen, A. Punkka, J. Rauhala, H. Hohti, D.M. Schultz //Mon Weather Rev. - 2009. - Vol. 137(7):2238-2249. https://doi.org/10.1175/2008MWR2707.1

24. Vasques T. Instability, Skew-T\& Hodograf. Handbook. [Text] / Vasques T. - 2017. - USA.

25. Webb R. Forecasting thunderstorms and severe thunderstorms using computer models [Text] / R. Webb, P. King // NSW Office. Commonwealth Bureau of Meteorology. Sydney. NSW. Australia. - 2009. - P. 67-76.

25. Webb J. (2001) Climatology of severe hailstorms in Great Britain [Text] / J. Webb, D. Elsom, D. Reynolds//Atmos Res. -.2001. - Vol. 56(14). - P. 291-308. https://doi.org/10.1016/S0169-8095(00)00081-8

26. Zhang C. Climatology of hail in China: 1961-2005. [Text] / C. Zhang, Q. Zhang, Y. Wang // J Appl Meteorol Climatol. - 2008. - Vol. 47(3). - P. 795-804.

27. Convective Season Environmental Parameters and Indices [Електронний ресурс]. - Режим доступу: http://wx.awcolley.com/Meteorology/ConvParmsIndices\#LIFTED

28. Wetterzentrale Tор Karten [Електронний ресурс]. - Режим достуny: https://www.wetterzentrale.de/ reanalysis.php?map

29. European Severe Weather Database: [Електронний ресурс]. - Режим доступy: http://www.eswd.eu/cgibin/eswd.cgi? \&lang=en 0

Authors Contribution: All authors have contributed equally to this work.

UDC 551.509 .5

Ellina Agayar,

$\mathrm{PhD}$ (Geography), Associate Professor,

Department of Meteorology and Climatology Odessa State Environmental University,

15 LvivskaStr, 65016, Odessa, Ukraine, e-mail: agayarellina@gmail.com, https://orcid.org/0000-0003-3914-6288;

Alina Semerhei-Chumachenko,

$\mathrm{PhD}$ (Geography), Associate Professor,

Department of Meteorology and Climatology Odessa State Environmental University, e-mail: asemergey2016@gmail.com, https://orcid.org/0000-0001-8718-4073;

\section{Svitlana Zubkovych,}

$\mathrm{PhD}$ (Geography), Associate Professor,

Department of Geoinformation technologies and space monitoring of the Earth,

Kharkiv National Aerospace University, 17 Chkalov Str, 61070, Kharkiv, Ukraine, e-mail: szubkovych@gmail.com, https://orcid.org/0000-0002-6839-7572

\section{APPLYING PREDICTION MODELS FOR SHORT-TERM HAIL FORECASTING IN SOUTHERN UKRAINE}

Formulation of the problem. Often natural disasters cause significant damage to the economy and the population, having a devastating nature, especially when a complex of dangerous weather conditions are created, which mutually reinforce their negative impact: storm rains accompanied by storm winds, thunderstorms with hail, etc. Increasing the validity and timeliness of storm warnings about hail occurrence is one of the main urgent tasks of operational meteorological support.

The geographical position of Ukraine, the diversity of climatic conditions and the features of the synoptic processes on its territory contribute to the complex spatial and temporal distribution of the occurrence of natural meteorological phenomena (NMP). In recent years, the frequency of extreme weather phenomena has increased due to significant climate fluctuations. Often natural disasters cause significant damage to the economy and the population, having a devastating nature, especially when a complex of dangerous weather conditions is created. These weather conditions mutually reinforce their negative impact: storm rains accompanied by storm winds, thunderstorms with hail, etc. Increasing the validity and timeliness of storm warnings about hail occurrence is one of the main urgent tasks of operational meteorological support. 
The purpose of the article to study the synoptic and thermodynamic conditions of large hail occurrence in the territory of southern Ukraine, as well as the possibility of using forecasting models for shortterm forecast of hail.

Methods. Using of high spatial resolution forecasting models and GFS objective data or other resources.

Results. The conditions of occurrence of two cases of hailstorms in the territory of the south of Ukraine in 2017-2018 are determined. In the first episode hail was not forecasted by the weather forecasters, due to the lack of daily radio-sounding data and a rare network of aerological observations, in the other one, an extraordinary hail $(\mathrm{D}=65 \mathrm{~mm})$ was observed. As predictors in forecasting of hail and other convective phenomena it is rational to use quantitative characteristics of the atmosphere instability. Possibilities of applying different convective storm indices, as well as the use of the Global Forecast System (GFS) numerical simulation forecast data with a grid step of $0.25 \mathrm{o} \times 0.25 \mathrm{o}$ meridians were evaluated. It has been found that the forecast of moving hail clouds is effectively implemented by using the Bunkers method.

Scientific novelty and practical significance. The most informative parameters of the thermodynamic state of the atmosphere the day before hail formation have been identified - Severe Weather ThrEAT Index (abbreviated SWEAT), Convective Available Potential Energy (abbreviated CAPE), Li (Lifted Index), BRN (Bulk Richardson Number), and VI (Boyden I). Recommendations are given to improve the quality of shortterm hail forecast, taking into account numerical simulation data.

Keywords: hail, spontaneous meteorological phenomena, convective processes, deep convection modeling, atmospheric instability indices.

\section{References}

1. Ashabokov B.A., Fedchenko L.M., Tapaskhanov V. O., Shapovalov A.V. et al. (2013). Fizika gradovykh oblakov $i$ aktivnykh vozdeystviy na nikh: sostoyaniye i napravleniya razvitiya [Physics of hail clouds and active impact on them: state and directions of development]. Nal'chik: OOO «Pechatnyy dvor», 216.

2. Buykov M.V., Kuz'menko A.G. (1978). O roste grada v superyacheykovykh gradovykh oblakakh [On the growth of hail in supercell hail clouds]. Meteorologiya i gidrologiya, 11, 6-15.

3. Bykov A.V., Vetrov A.L., Kalinin N.A. (2017). Prognoz opasnykh konvektivnykh yavleniy v Permskom kraye $s$ ispol'zovaniyem global'nykh prognosticheskikh modeley [Forecast of dangerous severe convective storm in the Perm Territory using global predictive models]. Trudy Gidromettsentra Rossii, 363, 101-119.

4. Hrushevs'kyy O.M., Mishchenko N.M., Mansarliys'kyy V.F., Burtsev V.M. (2018). Pro mozhlyvosti diahnozu $i$ prohnozu hlybokoyi konvektsiyi v operatyvniy diyal'nosti [On the opportunities of diagnosis and forecast of deep convection during operational activity]. Ukrayins'kyy hidrometeorolohichnyy zhurnal, 22, 5-15.

5. Danov Ye.I., Danova T.Ye. (2001). K analizu superyacheykovogo gradovogo shtorma v Prichernomor'ye [On the analysis of a supercellular hail storm in the Black Sea region]. Meteorologiya, klimatologiya i gidrologiya: Mezhvedomstvennyy nauchnyy sbornik Ukrainy, 44, 61-66.

6. Rukovodstvo k prognozu opasnykh osadkov, grada i shkvalov po dannym meteorologicheskikh radiolokatorov $i$ iskusstvennykh sputnikov Zemli [Guide to forecasting hazardous precipitation, hail and squalls based on data from weather radars and satellites] (1996). SPb.: Gidrometeoizdat.

7. Sulakvelidze G.K. (1968). Livnevyye osadki i grad [Heavy rainfall and hail]. L., Gidrometeoizdat, 412.

8. Stykhiyni meteorolohichni yavyshcha na terytoriyi Ukrayiny za ostannye dvadtsyatyrichchya (1986-2005rr.) [Natural meteorological phenomena on the territory of Ukraine for the last twenty years (1986-2005)] (2006). Za redaktsiyeyu V.M. Lipins'koho, V.I. Osadchoho, V.M. Babichenko. Ukrayins'kyy naukovo-doslidnyy hidrometeorolohichnyy instytut. Derzhavna hidrometeorolohichna sluzhba. Kyyiv, Nika-Tsentr, 312.

9. Tolmacheva N.I., Yermakova L.N. (2011). Issledovaniye parametrov oblachnosti i yavleniy po dannym sputnikovogo $i$ radiolokatsionnogo zondirovaniya [Research of cloudiness parameters and phenomena according to satellite and radar sounding data]. Geograficheskiy vestnik, 3.

10. Findayzen V, Shul'ts G. (1951). Eksperimental'nyye issledovaniya obrazovaniya ledyanykh chastits. Fizika obrazovaniya osadkov [Experimental studies of the ice particles formation; Physics of precipitation], M., 312.

11. Shmeter S. M. (1987). Termodinamika i fizika konvektivnykh oblakov [Thermodynamics and physics of convective clouds]. L., Gidrometeoizdat, 287.

12. Andersson T., Andersson M., Jacobsson C., Nilsson, S. (1969). Thermodynamic indices for forecasting thunderstorms in southern Sweden, Meteorol. Mag., 116, 141-146.

13. Bedka K.M. (2011). Overshooting cloud top detections using MSG SEVIRI infrared brightness temperatures and their relationship to severe weather over EuropeAtmos Res., 99(2), $175-189$. https://doi.org/10.1016/j.atmosres.2010.10.001

14. Browning K.A. (1975). Airflow and hail growth in super-cell storms and some implications for hail suppression. Nation. Hail Research Exper., 75/1.

15. Bunkers M.J. et al. (2000). Predicting supercell motion using a new hodograph technique. Weather and Forecasting, 15, 61-79.

16. Craven J.P. and H.E. Brooks (2004). Baseline climatology of sounding derived parameters associated with deep, 
moist convection. Natl. Wea. Dig., 28, 12-24.

17. Doswel C.A., Schultz D.M. (2006). On the use of indices and parameters in forecasting severe storm. Electron. J. Sev. Storms Meteorol., 1, 1-14.

18. Dworak R., Bedka K.M., Brunner J., Feltz W. (2012). Comparison between GOES-12 overshooting-top detections, WSR-88D radar reflectivity, and severe storm reports. Weather Forecast, 27(3), 684-699. https://doi.org/10.1175/WAF-D-11-00070.1

19. Fawbush E.F., and R.C. Miller (1953). A method for forecasting hailstone size at the earth's surface. Bull. Amer. Meteor. Soc., 34, 235-244.

20. Kahraman A., Tilev-Tanriover S., Schultz Severe D.M. (2016). Hail Climatology of Turkey. Monthly Weather Review, 144(1), 337-346 https://doi.org/10.1175/MWR-D-15-0337.1

21. Mossop S.C. (1982). The origin and concentration of ice crystals in clouds. Bull. Amer. Soc., 66, $264-273$.

22. Punge H. J., Bedka K. M., Kunz M., Werner A. (2014). A new physically based stochastic event catalog for hail in Europe. Springer. https://doi.org/10.1007/s11069-014-1161-0

23.Tuovinen J, Punkka A, Rauhala J, Hohti H, Schultz D.M. (2009). Climatology of severe hail in Finland: $1930-2006$. Mon Weather Rev 137(7), 2238-2249. https://doi.org/10.1175/2008MWR2707.1

24. Vasques T. (2017). Instability, Skew-T \& Hodograf. Handbook. Vasques T., USA.

25. Webb R., King P. (2009). Forecasting thunderstorms and severe thunderstorms using computer models. NSW Office. Commonwealth Bureau of Meteorology. Sydney. NSW. Australia, 67-76.

25. Webb J, Elsom D, Reynolds D (2001). Climatology of severe hailstorms in Great Britain. Atmos Res 56(14), 291308. https://doi.org/10.1016/S0169-8095(00)00081-8

26. Zhang C, Zhang Q, Wang Y (2008). Climatology of hail in China: 1961-2005. J Appl Meteorol Climatol 47(3), 795804.

27. Convective Season Environmental Parameters and Indices Available at: http://wx.awcolley.com/Meteorology/ ConvParmsIndices\#LIFTED

28. Wetterzentrale Top Karten Available at:https://www.wetterzentrale.de/reanalysis.php? map

29. European Severe Weather Database: Available at: http://www.eswd.eu/cgi-bin/eswd.cgi? \&lang=en 0 